H.Azzouz Rached, S. Yahyaoui, Dr. Sc. (Tech.)
Badji Mokhtar University, Annaba, Algeria, e-mail: azzouzrached@hotmail.com

\title{
APPLICATION OF THE TENSILE STRENGTH TO ROCK BLASTING
}

Purpose. Determination of the blastability index from rock strength properties, which employ load rate orders of magnitude that encountered in blasting. These results may be relevant to fragmentation by blasting. The resistance of rocks to blasting and the capability to apply the tensile strength tests and interpret them in relation with rock characterization.

Methodology. The direct uniaxial tensile strength, Brazilian test, and point load tests have been applied on rock material drilled out from the vicinity of blasting operation before and after blasting.

Findings. Unlike the point load tests, neither the Brazilian nor the uniaxial strength tests indicated a particular decrease in the strength of the remaining rock material after the blasting. The results of fracture frequency and rock quality designation showed a low degree of the damage caused to the remaining rock in part of the mass near the blast. On the basis of the results from the tests mentioned above, the low degree of the problems faced after the blasting may be explained with reference to the state of discontinuity of the rock material. In addition, the results suggest that more research must be conducted by the use of Brazilian and uniaxial tensile strength tests as methods for characterizing the rock strength for fragmentation.

Originality. The identification of the blastability index from the strength properties of rock and definition of characteristics of the rock strength for fragmentation.

Practical value. The findings obtained based on assessment of the strength properties of the rock can become the basis for the design of blasting in a site.

Keywords: strength, Brazilian tests, uniaxial tensile strength, rock mechanics, blasting, brittleness index

Introduction. The tensile strength of rocks is a significant mechanical property for engineering projects such as tunnels and slopes and rock blasting [1].

The importance of the tensile strength, as one of the parameters determining the resistance of rocks to blasting, has been maintained within the field of blasting research. In an early attempt to classify blasting resistance, it is suggested to use a "blastability index" which is defined as the ratio of the compressive and tensile strengths [2]. Such an index measures the amount of blastability of a rock. It would be much more advantageous for the blastability index defined before blasting in order to get the most accurate blast design of an excavation. Also, this index is used to ensure the blasting effectiveness, and it has a direct relationship to the fragmentation of the rock. It has also a relation with a Powder Factor which is defined as ratio of weight of explosive to tons of the material broken. Later, the tensile strength was incorporated in a formula aiming at the characterization of the rock resistance to blasting in the field of tunneling. Among later works, Zou and al [3] clarifies the appearance of radial cracks around a blasthole as a result of tangential tensile stresses first seeming a couple hole radii out from the blasthole divider. The spread of these cracks in bench blasting is, moreover, proven to be influenced by tensile waves, which are reflected from the front of the bench [4]. Results from examinations of the rest rock damage at blasting additionally reinforce researchers on the strength of rock materials. It has been demonstrated from assessments that removals arising in the rest of the rock are the consequences of the two developments in formerly existing joints and fracturing of the rock preceding blasting should be named intact [5]. Regarding the future work on characterization techniques utilizing dynamic strength tests and fracture mechanics standards, it is the point of this paper to discuss the possibility of applying and interpreting ordinary tensile strength tests regarding the characterization of rock blasting. To give a basis for a case, history will finally form the basis for conclusions.

The tensile strength of rocks. As it is referred to above, a rock tensile strength is a key parameter, which is commonly used in the design of blasting of a rock and its stability. There are several test types for measuring or deriving the tensile strength in the laboratory, like "Uniaxial direct tensile strength test", "Brazilian indirect tests", and "point load tests". There are many research studies intended to define the rocks' tensile strength. Since the early years of rock mechanics, the techno-

(C) Azzouz Rached H., Yahyaoui S., 2019 logy has unceasingly evolved and new methods for finding the tensile strength have been innovated.

The writing about rock mechanics contains an expansive number of papers regarding the matter of tensile testing of rocks. According to the international Society for Rocks Mechanics [6, 7], the two testing methods (the Brazilian and uniaxial tensile strength) are examined by Brisevac and Efimov $[8,9]$, and are often set to criticism [10].

The problem with the Brazilian test is that it is uncertain to recognize the failure point threshold and the indirect testing procedure, which assumes linearly elastic material behavior. Concerning the second test, the problem regards realizing a uniform distribution of stress on the sample. Since most rocks do not keep their form under tension; however, the tensile strength is an essential factor. According to the authors' opinion $[1,3,10]$, the tensile strength tests must be kept providing that the testing procedures are critically analyzed and interpretations are made with the purpose of controlling the uncertainties. Yet, both tests must be considered as essential rock material tests i.e. prototypes are prepared from core parts with no fracture. It is the authors' criticism that sufficient fragmentation rock material failure is required, at least for cases of competent rock with a low density of larger existing fractures.

In the following points, the proposed procedures for both tests are discussed.

The Brazilian test. Subsequently, this test, which is difficult to apply due to the above-mentioned reasons, has become the most commonly used indirect method [10].

For the Brazilian strength test, the test specimens are cylindrical. A piece with a diameter of $54 \mathrm{~mm}$ usually satisfies the criterion. The test specimen is located between two platens, which diametrically compress the sample to rupture. Prior knowledge of the stress circulation is needed in the loaded sample before the phase of rupture, which would be tested. There are notions about the stress for a line loaded sample of homogeneous, isotropic and linearly elastic material [11].

In the recommendations for the Brazilian tests published by the ISRM [12] it is mentioned that the specimen diameter must be over $54 \mathrm{~mm}$, the thickness should be equivalent to the specimen sweep and the loading rate should be to such an extent that failure in the weakest rocks will happen inside 15-30 seconds of loading. However, a loading rate of $200 \mathrm{~N} / \mathrm{s}$ is proposed. The ISRM, likewise, provides proposals on the preparation of the specimens. The tensile strength was stated by utilizing the accompanying equation 


$$
B T S=\frac{2 P}{\pi D t},
$$

where $P$ is the connected load at rupture, and $D$ and $t$ are the diameter and thickness of the rock specimen, separately.

The uniaxial tensile strength test. Moreover, this test is hard to measure because of a practical problem in holding rock specimen [13].

Different methods for the execution of the test are considered by Efimov [8]. Recommendations are given by the ISRM [12] and the American Society for Testing and Materials [6, 7]. The testing procedure is prescribed by the ASTM. To calculate the rock's direct tensile strength, a cylindrical shaped rock sample is stuck into metal end cups on both ends. The metal end tops are joined to material test systems loading outline; thus, the sample can be loaded in pressure till the point that it falls flat; the tensile stress applied at this point is then the rock's tensile strength.

The recommendations concerning sample dimensions and loading rates are presented in Tables 1 and 2. Watchful preparation is a concern if a uniform stress distribution is to be accomplished.

The testing procedure. The specimens were taken from research in situ and prepared from block of rock sample. The specimens having a $38 \mathrm{~mm}$ diameter were cut to length/diameter of 2.5. The diameter and the length of every sample were measured, and the mass of each specimen was determined just before testing. They were firmly attached to foil strain gauges of type N22-FA-5-120-H oriented axially and laterally. These pairs of the samples should be placed opposite each other in terms of their diameter and affixed on the specimens' centers. Throughout the process of testing, the pairs were attached with the pairs of gauges on 'artificial' sample away from the machine to obtain temperature variation compensation. A Wheatstone bridge was created and strain changes were followed and checked by variations in the voltage across the bridge. The load was observed and controlled with a pressure transducer. This resulted in obtaining a complete force-displacement curve for every sample on an $X-Y$ recorder. The remote $X-Y$ chart recorder, that was used to control the axial and the lateral displacement, which was identified by the strain gauges, controlled axial load as well. The tensile strength was taken from the peak of every curve.

Point load index (PLI). This test has been considered as a valuable testing method to appraise the strengths of rocks because of its easiness of, effortlessness of preparing sample, and conceivable field application [13].

The previous test can be found by exposing a rock sample to an inexorably tough load until the point when the sample bombs by part, the rupture load is then used to ascertain the index. The concentrated load is done by circularly truncated, cone-like platens of a standard geometry.

Table 1

Recommendations concerning specimen geometry uniaxial tensile strength test

\begin{tabular}{|l|c|c|}
\hline \multicolumn{1}{|c|}{ Specimen } & ASTM [6, 7] & ISRM [12] \\
\hline length /diameter & $2.0-2.5$ & $2.5-3$ \\
\hline diameter & $48 \mathrm{~mm}$ & $54 \mathrm{~mm}$ \\
\hline
\end{tabular}

Table 2

Recommendations concerning loading rate uniaxial tensile strength test

\begin{tabular}{|l|l|l|}
\hline & \multicolumn{1}{|c|}{ ASTM [6, 7] } & \multicolumn{1}{c|}{ ISRM [12] } \\
\hline $\begin{array}{l}\text { Loading } \\
\text { rate }\end{array}$ & $\begin{array}{l}\text { rupture should occur } \\
\text { after 5-15 min of }\end{array}$ & $\begin{array}{l}\text { rupture should occur within } \\
5 \text { min. of loading (alternatively } \\
\text { loading }\end{array}$ \\
\hline
\end{tabular}

The findings from tensile strength tests done on rock material from the surrounding area of a blasting process and its results. With the purpose of making a detailed investigation of the strength and the fracturing of the vicinity rock, cores were taken out before and after the blasting of a bring up in the Kenadsa ore-body of the underground mine (Fig. 1) and with geological conditions. This underground mining located 12 miles on the boundaries of Bechar, reflecting distinctive rock materials that can significantly affect the underground mining task. The application of the blasting activity is shown in Table 3, and it was embraced by Onex in participation with the University of Badji Mokhtar Annaba, Department of mining as a piece of research on the utilization of extensive holes in underground mining.

The cores were analyzed regarding fracture frequencies and RQD-value samples for the Brazilian tests and uniaxial tensile strength tests were arranged and assessed. At last, point load tests were additionally applied. The essential point was to identify the damage to the rock surrounding the raise regarding fracture frequencies and RQD-values and by utilizing the strength to recognize little scale rock damage. As a working speculation, it was accepted that a growth of the length of cracks and microcracks could be distinguished utilizing results from uniaxial tensile Strength tests and Brazilian tests as demonstrated by the results in Table 4 .

Prior to the uniaxial tensile strength tests, the working of the load application framework was considered utilizing an aluminum specimen with tour axial gauges for strain estimations. The calculations of the eccentricity for three tests performed up to a load comparing to a normal tensile stress of 6.4 MPa brought about eccentricities under $2.5 \%$ at the greatest load. The data on the execution of the Brazilian tests and uniaxial tensile strength tests are outlined in Table 5.

The results from the Brazilian tests performed prior to and after blasting are demonstrated in Fig. 2. The results were con-

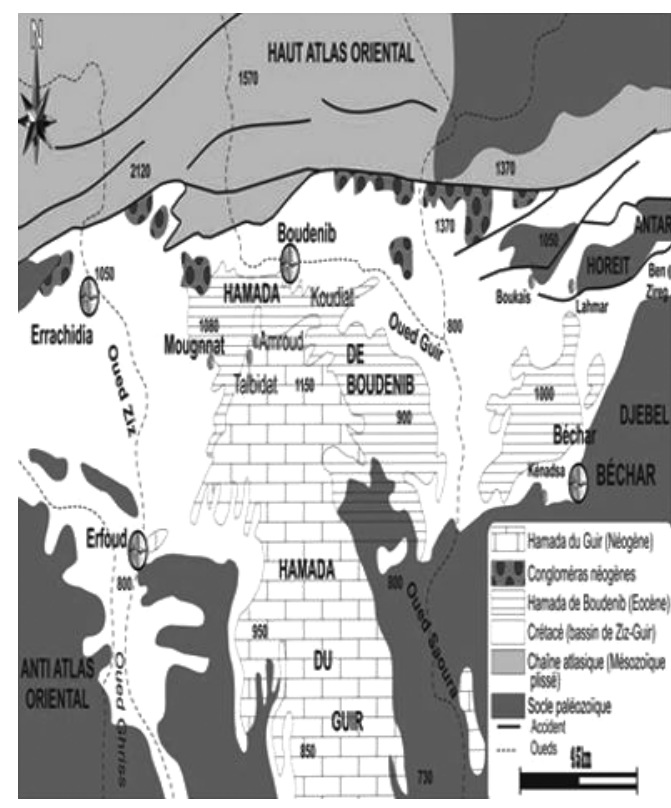

Fig. 1. Geographic situation of Kenadsa underground mine Béchar

Table 3

Data from VCR-bringing up in the Kenadsa mine

\begin{tabular}{|l|c|l|}
\hline \multicolumn{1}{|c|}{ Area of raise } & Diameter of charge holes & \multicolumn{1}{|c|}{ Explosives } \\
\hline $\begin{array}{l}\text { Between the } 494 \text { and } \\
530 \mathrm{~m} \text { levels }\end{array}$ & $102 \mathrm{~mm}$ & $\begin{array}{l}\text { Dynamex } \\
\text { and ANFO }\end{array}$ \\
\hline
\end{tabular}


Table 4

The effect of cracks length on the tensile strength ratio

\begin{tabular}{|l|c|c|}
\hline \multicolumn{1}{|c|}{ Rock type } & cracks length $(\mathrm{mm})$ & $\sigma_{T} / \sigma_{B T}$ \\
\hline Limestone & 0.2 & 1.0 \\
& $1-5$ & 0.45 \\
& $3-5$ & 0.47 \\
& $2-6$ & 0.31 \\
\hline Granite & $<0.1$ & 0.93 \\
& 0.3 & 0.7 \\
& $1-3$ & 0.50 \\
& $2-5$ & 0.34 \\
& $1-10$ & 0.14 \\
Basalt & $3-20$ & 0.07 \\
& $<0.1$ & 0.9 \\
& $2-20$ & 0.15 \\
\hline
\end{tabular}

Table 5

Data on the execution of strength tests

\begin{tabular}{|l|c|c|}
\hline & \multicolumn{1}{|c|}{ Brazilian tests } & $\begin{array}{c}\text { Uniaxial tensile } \\
\text { strength tests }\end{array}$ \\
\hline Specimen diameter & $31.5 \mathrm{~mm}$ & $31.5 \mathrm{~mm}$ \\
\hline Specimen length & \multicolumn{1}{|c|}{$=$ radius } & twice the diameter \\
\hline Speed of loading & $\begin{array}{l}0.12 \mathrm{~cm} / \text { minute } \\
(\text { failure within } 15-30 \mathrm{~s})\end{array}$ & $\begin{array}{l}0.60 \mathrm{MPa} / \text { minute } \\
(9 \mathrm{MPa} \text { in } 15 \text { minutes })\end{array}$ \\
\hline Load distribution & $\begin{array}{l}\text { Cardboard sheets, thickness }=0.3 \mathrm{~mm} \\
\left(2 \alpha=8-11^{\circ}\right)\end{array}$ \\
\hline $\begin{array}{l}\text { Treatment of } \\
\text { specimens }\end{array}$ & $\begin{array}{l}\text { Stored for } 24 \mathrm{~h} \text { at a temperature of } 100{ }^{\circ} \mathrm{C} \\
\text { before testing }\end{array}$ \\
\hline
\end{tabular}

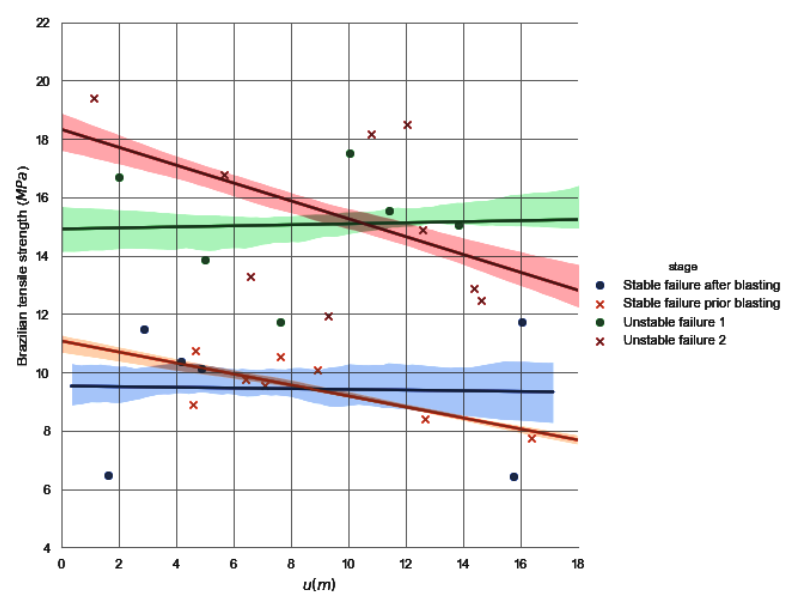

Fig. 2. Results from Brazilian tests

ceivable to separate into gatherings alluding to two modes of rupture, here indicated stable and unstable ruptures:

1. With the rupture along the line of loading, expansion of the cracks was restricted to the central part of the specimen. Areas around points of loading are just somewhat or not under any condition fractured. Specimen parts are not totally isolated (Stable rupture).

2. The rupture occurs along the line of loading cracks near the points of loading and in different directions in the specimen. Specimen parts are totally isolated (Unstable rupture).

Significance testing uncovered a significant distinction between the normal tensile strengths $\sigma_{B T}$, for the two gatherings of results. The regression line and $95 \%$ confidence limits demonstrate the variety of $\sigma_{B T}$, along the cores for stable rup- tures only. No significant contrast was obtained between the results acquired prior to and after blasting.

The results for the uniaxial tensile strength tests are presented in Fig 3. Since no real distinction between the uniaxial tensile strengths $\sigma_{T}$, prior to and after blasting was obtained, and the regression line and the confidence limits have been determined dependent on every one of the results.

Fig. 4 demonstrates a variety of the point load strength index, which is significantly more similar to the results from the uniaxial tensile strength tests than to the results from the Brazilian tests.

$I_{S}$ values less than $2 \mathrm{MPa}$ were ignored in the calculation of regression and confidence limits.

From the results in Figs. 2 and 3 it was reasoned that no large decrease in the tensile strength had happened because of the blasting; it was, notwithstanding, noticed that the varieties of the tensile strengths along the cores as given by the regression lines result in $\sigma_{T} / \sigma_{B T}$-ratios concur with the ones obtained, which strengthened utilizing tensile strength test results as a methods for characterizing the condition of fissuring of the rock.

The findings from the blasting of the raise are reported by Kewei Liu [14].

Throughout the operation, several problems were faced. Charge hole deviations were larger than expected. Regardless of the way in which some re-drilling was made, this resulted in greater distances between corner holes and the middle hole than was initially arranged, especially in the lower parts of the raise. Issues were, furthermore, encountered in the estimating of the position of the rock surface after blasting and in the stopping of holes, the last issue being halfway caused by a propensity for the charge holes to wind up narrowly formed after blasting. Together with other possible factors of influence, these problems were reflected in the blasting findings. In the initial stage of the work where dynamite cartridges $(7 \mathrm{~kg}$ in every hole) were used, only approximately $25 \%$ of the craters, which were formed, reached the stipulated depth of $1.4 \mathrm{~m}$.

After changing the explosive to ANFO, larger crater depths were obtained. The amount of explosive was, however, also increased (5-24 kg in every hole). Identifying a single factor as the one causing the problems and the unexpectedly bad result of the blasting is a difficult task; it was anyway expressed by Kewei, Liu [14] to a noteworthy degree, and the blasting results appeared to rely upon the structure of the rock.

A different method to the investigation of the rock resistance to blasting is to examine the remaining rock damage.

Fig. 5 demonstrates the results from the determinations of RQD-values prior to and after blasting. In the estimations all fractures separating core parts were utilized.

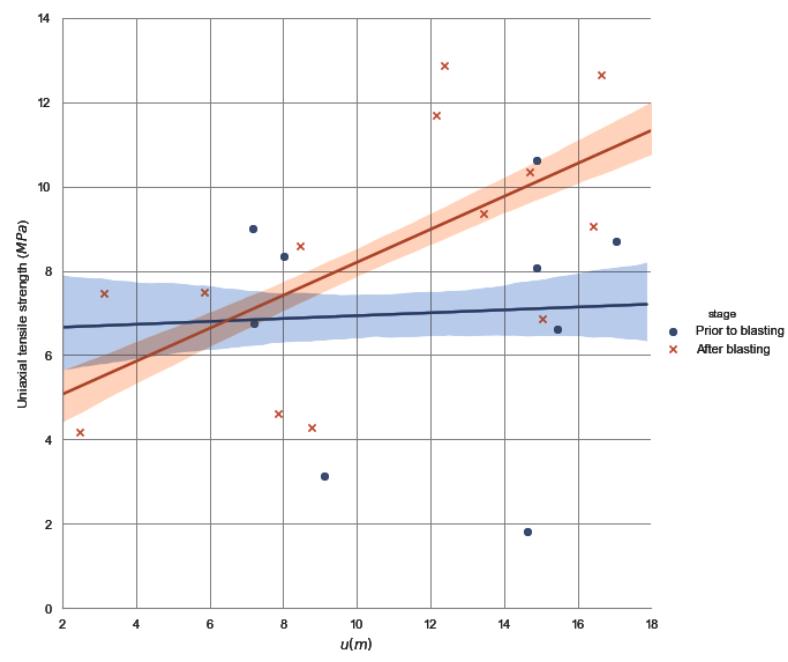

Fig. 3. Results from uniaxial tensile strength tests 


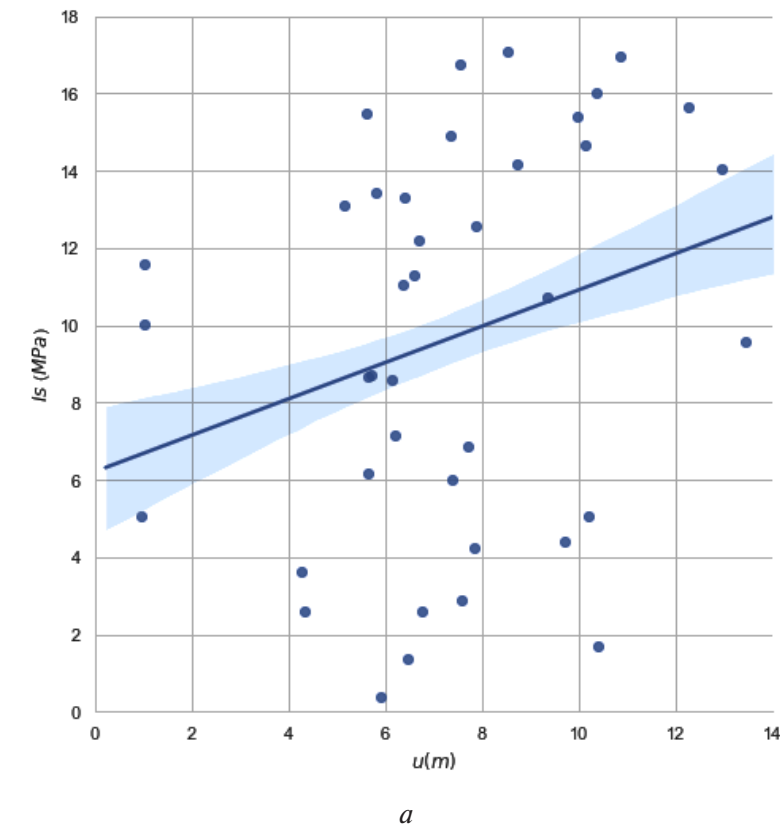

Fig. 4. The point load strength index IS:

$a$ - prior to blasting; $b$ - after blasting

No significant decrease in the rock quality was obtained for the rock mass nearest to the raise. For the rock mass nearer to the drift, anyway, a decrease in the rock quality was noted. Similarly, the results of fracture frequency computations, (Figs. 6 and 7), indicated a low relative increase in the fracture frequency in the rock mass closest to the raise. Based on the results in Figs. 5 to 7, we conclude that an unexpectedly low degree of damage was obtained close to the raise.

Results. The general accord between the results from the Brazilian tests and the uniaxial tensile strength tests affirm the validity of the conclusions concerning the Brazilian test given by Efimov [8].

In an authentic test, only a diametric crack should be taken into consideration.

The result in $\sigma_{T} / \sigma_{B T}$ ratios as indicated in Table 4, were performed under conditions to some degree varying from the ones pursued at the experiments presented here. The Brazilian tests were, for example, performed on specimens with a diameter of $40 \mathrm{~mm}$, a thickness equivalent to the diameter and with a load distribution angle of $23^{\circ}$.

An examination of the influences of the discrepancies, anyway, does not indicate that different results should be expected from the two methods of testing. It may thus be concluded that the results from the experiments give $\sigma_{T} / \sigma_{B T}-$ ratios, which may be interpreted as reflecting the condition of

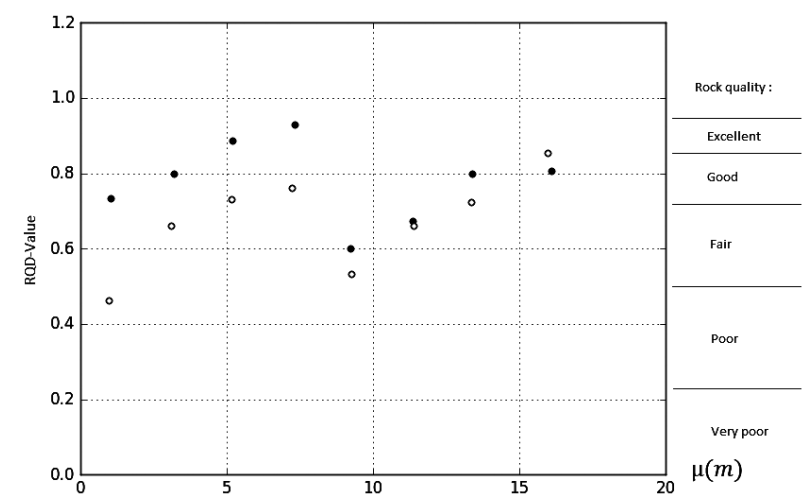

Fig. 5. The determinations of RQD-values prior to and after blasting

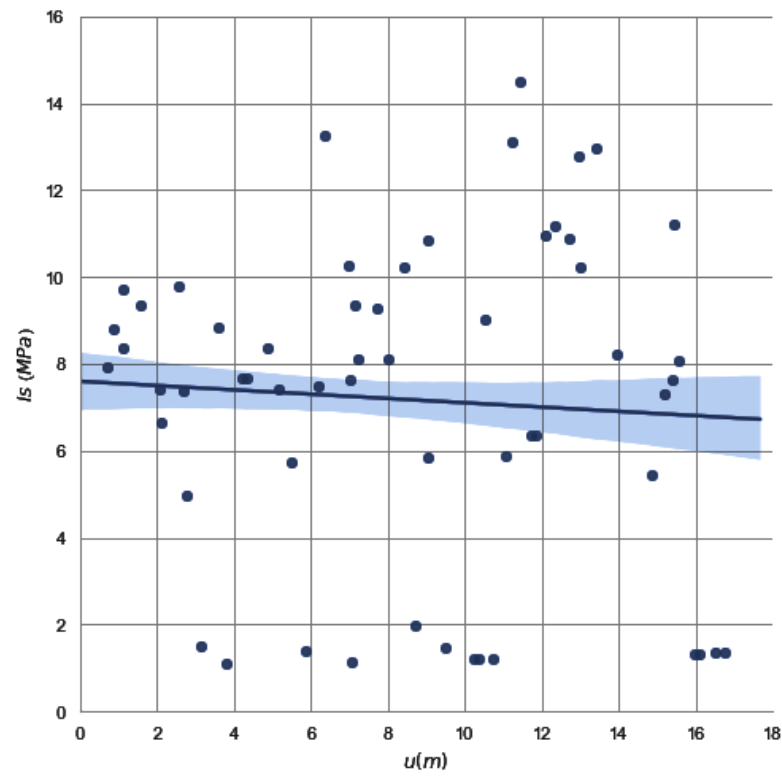

$b$

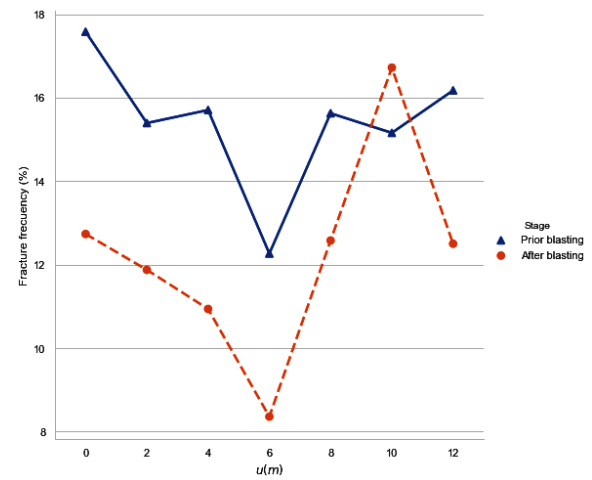

Fig. 6. Fracture frequencies prior to and after blasting

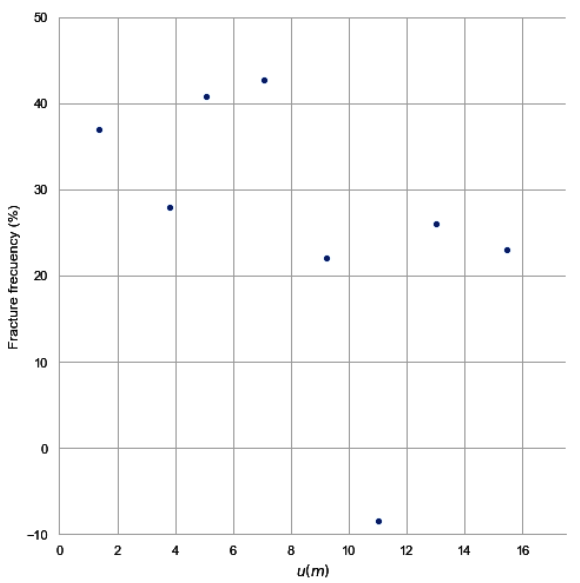

Fig. 7. Relative increase in fracture frequencies

fissuring of the rock material. Looking at the results of the blasting and from the examination of the remaining rock damage, the experienced high resistance of the rock might be clarified as a result of a current condition of fissuring characterized by short fissures as opposed to longer ones. In the parts of the rock mass nearer to the drift a decreased rock quality was obtained. As would be expected from this line of reasoning, the 
tests of the tensile strength on this side of the rock mass demonstrate a state of fissuring more characterized by longer fissures. The findings from the examinations subsequently demonstrate that more consideration should be taken to the regular tests of tensile strength because they can be utilized to give data about the rock's little scale structures. For future applications regarding blasting, more research could prompt valuable findings relating to the tensile strength, the condition of fissuring and the rock resistance to fragmentation.

An observation can be realized after obtaining the outcomes from the point load tests. Starting from this index, the compressive strength of the rock material could then be calculated using different relations as proposed by [15]. The results also indicated an existing relation between this index and the uniaxial tensile strength [16, 17], which strongly support the relations identified before.

Conclusions. The Brazilian tests presented in this paper provided equivalent or higher medium strength values in comparison with the tests of uniaxial tensile strength in the case of prior and after blasting.

In the paper, a referenced investigation has given similar relation between the two mentioned tests whose results were obtained.

As we referred to previously, this relation demonstrates that the Brazilian test provides the strength of the unfissured rock matrix or, in other words, the intrinsic tensile strength. Following this line of reasoning first recommended by scientists in question, according to the structuring of the rock material, the link between them could be considered as a reflecting strength against stressed volume relation.

Relations between Brazilian and uniaxial tensile strength test findings were obtained. This indicates that the Brazilian test is less sensitive to specimen size and the contents of fissures and gives the strength of the unfissured rock matrix or in other words the intrinsic tensile strength.

At this stage of development, nevertheless, we should not overlook any of the static tests since the characterization is performed in tensile stress fields.

Acknowledgement. This research work was carried out at Annaba University, Algeria, under the sponsorship of the Natural Resources and Amenagement Laboratory, Mineral Processing and Environmental Research Laboratory, whose financial and technical assistance is gratefully acknowledged.

\section{References.}

1. Torabi, S. R., Shirazi, H., Hajali, H., \& Monjezi, M. (2013). Study of the influence of geotechnical parameters on the TBM performance in Tehran-Shomal highway project using ANN and SPSS. Arab J Geosci, (6), 1215-1227. DOI: 10.1007/ s12517-011-0415-3.

2. Zhang, Z.X. (2016), Rock Fracture and Blasting: Theory and Applications. Oxford: Elsevier. DOI: 10.1016/C2014-0-01408-6. 3. Zou, D. (2017). Mechanisms of Rock Breakage by Blasting. In: Theory and Technology of Rock Excavation for Civil Engineering. Springer, Singapore. DOI: 10.1007/978-981-10-1989-0_5. 4. Torbica, S., \& Lapčević, V. (2015). Estimating extent and properties of blast-damaged zone around underground excavations. Rem: Revista Escola de Minas, (68), 441-453. DOI: 10.1590/0370-44672015680062.

5. Verma, H. K., \& Prasad, V.V.R. (2014). Blast Induced Damage to Surrounding Rock Mass in an Underground Excavation. Journal of Geological Resource and Engineering, (2), 1319. Retrieved from http://cimfr.csircentral.net/id/eprint/1788. 6. Komurlu, E., \& Demir, S. (2019). Drilled Core Specimen Testing Method for Determination of Tensile Strength Values of Rock Materials. Periodica Polytechnica Civil Engineering, 63(1), 18-24. DOI: 10.3311/PPci.12524.

7. Fuenkajorn, K., \& Klanphumeesri, S. (2011). Laboratory Determination of Direct Tensile Strength and Deformability of Intact Rocks. Geotechnical Testing Journal, 34(1), 97-102. DOI: $10.1520 /$ GTJ103134.
8. Efimov, V. P. (2016). Tensile strength of rocks by test data on disc-shaped specimens with a hole drilled through the disc center. Journal of Mining Science, 52(5), 878-884. DOI: 10.1134/S1062739116041334.

9. Brisevac, Z., Kujundzic, T., \& Cajic, S. (2015). Current cognition of Rock Tensile Strength by Brazilian Test. MiningGeol.-Petrol. Eng. Bull., 30(2), 101-114. DOI: 10.17794/ rgn.2015.2.2.

10. Fahimifar, A., \& Malekpour, M. (2012). Experimental and numerical analysis of indirect and direct tensile strength using fracture mechanics concepts. Bull Eng Geol Environ, 2(71), 269-283. DOI: 10.1007/s10064-011-0402-7.

11. Li, D., \& Wong, L. N. Y. (2013). The Brazilian disc test for rock mechanics applications: review and new insights. Rock Mech Rock Eng, 46, 269-287. DOI: 10.1007/s00603-0120257-7.

12. Ulusay, R. (2007-2014). The ISRM Suggested methods for rock characterization Testing and Monitoring. Springer International Publishing, Switzerland 2015, pp. 1-293, DOI: 10.1007/978-3-319-07713-0.

13. Ren, F., Liu, H., He, R., Li, G., \& Liu, Y. (2018). Point Load Test of Half-Cylinder Core Using the Numerical Model and Laboratory Tests: Size Suggestion and Correlation with Cylinder Core. Advances in Civil Engineering, 1-11. DOI: 10.1155/2018/3870583.

14. Kewei Liu, Xudong Lia, Hong Haob, Xibing Lia, Yanyan Shad, Weihua Wanga, \& Xiling Liu (2018). Study on the raising technique using one blast based on the combination of long-hole presplitting and vertical crater retreat multiple-deck shots. International Journal of Rock Mechanics and Mining Sciences, 113, 41-58. DOI: 10.1016/j.ijrmms.2018.11.012.

15. Kahraman, S. (2014). The determination of uniaxial compressive strength from point load strength for pyroclastic rocks. Engineering Geology, 170, 33-42. DOI: 10.1016/j.enggeo.2013.12.009.

16. Perras, M.A., \& Diederichs, M.S. (2014). A Review of the Tensile Strength of Rock: Concepts and Testing. Geotechnical and Geological Engineering, 32(2), 525-546. DOI: 10.1007/ s10706-014-9732-0.

17. Kabilan, N., \& Muttharam, M. (2016). Correlation between Unconfined Compressive Strength and Indirect Tensile Strength for Jointed Rocks. International Journal of Research in Engineering and Technology, 5, 157-161, DOI: 10.15623/ ijret.2016.0505029.

\section{Застосування міцності на розрив до вибуху породи}

\section{Х. Аззуз Рашед, С. Яхяуї}

Університет Баджі Мохтар, м. Аннаба, Алжир, e-mail: azzouzrached@hotmail.com

Мета. Визначення фактора вибуховості, виходячи з міцнісних властивостей порід із застосуванням порядку величини інтенсивності навантаження, що зустрічаються при вибухових роботах. Ці результати можуть мати відношення до дроблення вибуховими роботами. Міцність гірських порід при вибухових роботах і можливість застосовувати тестування міцності на розрив та інтерпретувати їх у відношенні визначення характерних ознак гірських порід.

Методика. Із використанням елементів скельних порід, узятих із місць проведення вибухових робіт до та після вибухів, були застосовані наступні методи: межа міцності при одноосьовому розтягуванні, бразильський метод, а також метод співвісних конічних пуансонів.

Результати. На відміну від випробування за методом співвісних пуансонів, ні бразильський метод, ні тестування межі міцності при одноосьовому розтягуванні не показали певного зниження міцності елементів породи 
після підривних робіт. Результати показника частоти виникнення тріщин і показника міцності порід указують на низький ступінь пошкоджень, викликаних у решти порід маси в зоні вибухових робіт. На підставі результатів описаних вище методів, низький ступінь виникнення проблем після вибухових робіт можна пояснити, посилаючись на стан нерозривності скельних порід. Більш того, результати передбачають проведення більш широкого дослідження із застосуванням бразильського методу й тестування межі міцності при одноосьовому розтягуванні як методів визначення характеристик міцності порід для дроблення.

Наукова новизна. Полягає у визначенні індексу вибуховості із міцних властивостей порід і визначенні характеристик міцності порід для дроблення.

Практична значимість. Результати, отримані з оцінки міцних властивостей порід, можуть стати основою для розробки вибухових робіт на дільниці.

Ключові слова: міцність, бразильський метод, межа міцності при одноосьовому розтягуванні, механіка гірських порід, підривні роботи, коефіцієнт чутливості грунту

\section{Применение прочности на разрыв к взрыву породы}

\author{
Х. Аззуз Рашед, С. Яхяуи
}

Университет Баджи Мохтар, г. Аннаба, Алжир, е-mail: azzouzrached@hotmail.com

Цель. Определение фактора взрываемости, исходя из прочностных свойств пород с применением порядка величины интенсивности нагрузки, которые встречаются при взрывных работах. Эти результаты могут иметь отношение к дроблению при взрывных работах. Прочность горных пород при взрывных работах и возможность применять тестирование прочности на разрыв и интерпрети- ровать их в отношении определения характерных признаков горных пород.

Методика. С использованием элементов скальных пород, взятых из мест проведения взрывных работ до и после взрывов, были применены следующие методы: предел прочности при одноосном растяжении, бразильский метод, а также метод соосных конических пуансонов.

Результаты. В отличие от испытания по методу соосных пуансонов, ни бразильский метод, ни тестирование предела прочности при одноосном растяжении не показали определенного снижения прочности элементов породы после взрывных работ. Результаты показателя частоты возникновения трещин и показателя прочности пород указывают на низкую степень повреждений, вызванных у оставшейся части пород массы в зоне взрывных работ. На основании результатов описанных выше методов, низкую степень возникновения проблем после взрывных работ можно объяснить, ссылаясь на состояние неразрывности скальных пород. Более того, результаты предполагают проведение более широкого исследования с применением бразильского метода и тестирования предела прочности при одноосном растяжении как методов определения характеристик прочности пород для дробления.

Научная новизна. Заключается в определении индекса взрываемости из прочностных свойств пород и определении характеристик прочности пород для дробления.

Практическая значимость. Результаты, полученные из оценки прочностных свойств пород, могут стать основой для разработки взрывных работ на участке.

Ключевые слова: прочность, бразильский метод, предел прочности при одноосном растяжении, механика горных пород, взрывные работы, коэффициент чувствительности грунта

Рекомендовано до публікації Корічі Талхі. Дата надходження рукопису 22.12.18. 